\title{
PENGARUH SISTEM JARAK TANAM DAN PEMBERIAN EM-4 \\ TERHADAP PERTUMBUHAN DAN PRODUKSI TANAMAN CABAI RAWIT (Carpsicumfrutescens L.)
}

\author{
Said AR. Assagaf \\ Staf Pengajar Program Studi Agroteknologi Fakultas Pertanian dan Kehutanan Universitas Iqra Buru, \\ e-mail: saidabdurahmanasegaf@gmail.com
}

ABSTRAK

Penelitian ini dilaksanakan di Desa Karang Jaya, Kecamatan Namlea, Kabupaten Buru, berlangsung dari bulan Nopember 2016 sampai Februari 2017. Tujuan dari penelitian ini adalah untuk mengetahui pengaruh jarak tanam dan EM-4 terhadap pertumbuhan dan perkembangan tanaman cabai rawit (capsicum frutescens). Penelitian ini menggunakan Rancangan Acak Kelompok (RAK) dengan pola faktorial yang terdiri atas 2 faktor. Adapun faktor pertama adalah Jarak Tanam (J) terdiri dari 3 taraf, yaitu J1 $(40 \mathrm{~cm} \times 60 \mathrm{~cm}), J 2(50 \mathrm{~cm} \times 60 \mathrm{~cm}), J 3$ $(60 \mathrm{~cm} \times 60 \mathrm{~cm})$. Faktor kedua adalah EM-4 (E) yang terdiri dari 3 taraf, yaitu E0 (Kontrol), E1 (150 L/ha) dan E2 (300 L/ha), diperoleh 9 kombinasi perlakuan dengan 3 ulangan sehingga terdapat 27 unit percobaan. Hasil penelitian menunjukkan bahwa kombinasi perlakuan jarak tanam $60 \mathrm{~cm} \times 60 \mathrm{~cm}$ dan EM-4 konsentrasi $300 \mathrm{~L} / \mathrm{ha}$ (J3E2) lebih baik dibandingkan perlakuan lainnya, ini dapat dilihat pada produksi berat buah per petak yaitu $6,64 \mathrm{~kg}$.

Kata kunci: \$M-4, Jarak Tanam, Pertumbuhan, Cabe Rawit

\section{PENDAHULUAN}

1.1. Latar Belakang

Cabai rawit merupakan tanaman perdu dari family terong-terongan (solanaceae) yang memeiliki nama ilmia Capsicum sp. Cabai berasal dari benua Amerika tepatnya daerah peru dan menyebar ke Negara-negara benua Amerika, Eropa dan asia termaksud Negara Indonesia dan Asia Tenggara lainnya (Setiadi,2008).

Tanaman cabai rawit dalam bahasa latinnya Capsicum frustescens $L$. Tumbuhan ini berasal dari Amerika tropika, yang menyukai daerah kering di temukan pada ketinggian 0,5 hingga 1250 meter di atas permukaan laut.Bagi masyarakat Indonesia, buah cabai merupakan salah satu bahan yang tidak di bisa dipisahkan dengan masakan sehari-hari . dalam 100 gram cabai rawit mengandung 103 kal energi, $4.7 \mathrm{~g}$ protein, $2.4 \mathrm{~g}$ lemak, $19.9 \mathrm{~g}$ karbohidrat, $45 \mathrm{mg}$ kalsium, $8 \mathrm{mg}$ fosfor, vitamin A $11 \mathrm{mg}$, vitamin C 70 mg. Buahnya mengandung kapsaisin, kapsantin, karotenoid, alkaloid atsiri, resin, minyak menguap, vitamin (A dan C). kapsaisin memberikan rasa pedas pada cabai, berkahsiat untuk melancarkan aliran darah serta pemati rasa kulit. Biji cabai rawit mengandung solanine, solamidine, solamargarine, solasodine, solasomine dan steroid (Rahman, 2010).

Disamping sebagai konsumsi dalam negeri cabai rawit juga merupakan komoditi ekspor yang tinggi nilainya. Untuk memperoleh hasil yang lebih tinggi, banyak factor yang harus diperhatikan, salah satu di antaranya adalah tersedianya unsur-unsur hara di dalam tanah, baik unsur hara makro maupun mikro (http://www.iptek.net.id/ind/obat/29/10/2016).

Cabai rawit dapat tumbuh baik di dataran tinggi maupun dataran rendah. Bertanaman cabai rawit dapat memberikan nilai ekonomis yang cukup tinggi apabila di usahakn dengan sunggusungguh. Satu hektar tanaman cabai rawit mampu menghasilkan 8 hingga 12 Ton buah cabe rawit karena tanaman cabe rawit dapat kita usahakan selama dua sampai dua setenga tahun selama musim tanam. Adapun manfaat cabai rawit kaya dengan vitamin $A$, selain manjur 
untuk mencegah kebutaan, juga dapat menyembuhkan sakit tenggorokan.

Jarak tanam berpengaruh pada tanaman cabai rawit, pengaturan jarak tanam dengan kepadatan tertentu bertujuan memberi ruang tumbuh pada setiap tanaman agar tumbuh dengan baik. Jarak tanam akan memenuhi kepadatan dan efesiensi penggunaan cahaya, persaingan diantara tanaman dalam penggunaan air dan unsu hara sehingga akan mempengaruhi produksi tanaman. Pada kerapatan rendah, tanaman kurang berkompetisi dengan tanaman lain, sehingga penampilan individu tanaman lebih baik. Sebaliknya pada kerapatan tinggi, tingkat kometisi diantara tanaman terhadap cahaya, air dan unsur hara semakin ketat sehingga tanaman dapat terhambat pertumbuhanya (Hidayat 2008).

Secara fisiologi jarak tanam akan menyangkut ruang dan tempat tanaman hidup dan berkembang. Maka, bila jika jarak tanam terlalu sempit akan terjadi persaiangan dalam memperoleh unsur hara, air, sinar matahari, dan tempat untuk berkembang. Jarak tanam juga tidak dipengaruhi oleh habitat tanaman dan luas perakaran, tetapi juga faktor lainya yang dapat mempengaruhi turunya produktifitas tanaman yang mendapat kerugian bagi petani (Susanto, 2002).

Jarak tanam yang optimal atau jarak tanam yang baik dipengaruhi berbagai faktor. Faktorfaktor yang dipengaruhi diantaranya sifat klon yang ditanam, bentuk wilayah (topografi) dan kerapatan yang dikehendaki dan sebagainya sehingga menjadi faktor - faktor yang mempengaruhi tumbuhan. Pada lahan yang datar dan agak landai digunakan jarak tanam yang bisa, tetapi untuk daerah yang miring, harus digunakan sistem kontur supaya tidak menjadi kompetisi antara tanaman (Setyamidjaja, 2000).

Menurut Hariadi (1994), perlakuan yang baik saat pembibitan bertujuan untuk memberikan faktor lingkungan yang lebih tepat selama awal pertumbuhan bibit agar dapat menjamin pertumbuhan bibit yang baik. Pembibitan yang baik dalam hal ini menyangkut penyediaan benih salah satunya usaha yang digunakan untuk merangsang dan menunjang pertumbuhan awal bibit yaitu melalui penggunaan EM4.

Pertumbuhan dan perkembangan tanaman ditentukan oleh sejumlah faktor dari tanah dan iklim dan oleh dari tanaman itu sendiri. Manusia dapat mempengaruhi penyediaan unsur-unsur hara dalam tanah melalui pupuk. Pupuk ialah bahan yang diberikan kedalam tanah baik yang organik maupun yang anorganik dengan maksud untuk mengganti kehilangan unsur hara kedalam tanah dan bertujuan untuk meningkatkan produksi tanaman dalam keadaan faktor keliling atau lingkungan yang baik. Pupuk dapat dibedakan menjadi dua jenis yaitu pupuk organik maupun pupuk anorganik. Pupuk anorganik adalah pupuk yang dibuat oleh pabrik dengan meramu bahan-bahan kimia (anorganik) yang berkadar tinggi. Pupuk organik merupakan alternatif penggunaan input pertanian ramah lingkungan (bahannya alami) murah (berasal dari limbah pertanian, rumah tangga) dan mudah, selain itu pupuk organik dapat memperbaiki sifat fisik tanah. Pupuk organik berdasarkan bentuknya secara umum di bedakan menjadi dua, yaitu pupuk padat dan pupuk cair, pupuk padat seperti pupuk kandang, kompos, bokasi dan lain-lain. Sedangkan pupuk organik cair seperti bio urine dan bio darah. yang sering digunakan dimasyarakat untuk meningkatkan produksi biasanya adalah EM-4 (effectif mikroorganisme ).

Effectife mikroorganisme

(EM-4) merupakan bahan yang mengandung beberapa mikroorganisme yang terdapat dalam EM-4 terdiri dari lumbricus (bakteri asam laktat) serta sedikit bakteri Fotosintetik, Actinomycetes, Streptomyces $\mathrm{Sp}$ dan ragi. Effective microorganisme (EM-4) dapat meningkatkan fermentasi limbah dan sampah organik. Miningkatkan ketersediaan unsur untuk tanaman, serta menekan aktifits serangga. (Djuarnani dkk, 2005).

Mikro organisme yang terdapat dalam EM4 secara genetika bersifat asli bukan genetika. Aplikasi EM4 bisa melelui berbagai cara, diantaranya sebagi larutan stok EM4 dan estrak tanaman yang di fermentasi dengan EM4, selalu memperbaiki kualitas fisik, kimia, dan biologi tanah, aplikasi EM4 mempunyai beberapa 
keuntungan lain, salah satunya adalah meneken pertumbuhan hama dan penyakit tanaman dalam tanah, membantuk meningkatkan kualitas bahan organik sebegai pupuk. Disamping itu juga dapat meningkatkan kualitas pertumbuhan vegetatif dan generatif tanaman seperti perkecambahan, pembungaan, pembuahan, pembentukan buah, proses pematangan buah. Aplikasi EM-4 juga ramah lingkungan dan tidak melakukan residu. ( Novizan, 2002).

\subsection{Tujuan Penelitian}

Penelitian ini bertujuan untuk mengetahui jarak tanam dan pengaruh pemberian EM4 terhadap pertumbuhan dan produksi tanaman cabe rawit (Capsicum frutescens $\mathrm{L}$.).

\section{METODE PENELITIAN}

Penelitian ini dilaksanakan pada bulan Februari sampai dengan April 2017. Pelaksanaan penelitian ini di desa Karang Jaya, Kecamatan Namlea, Kabupaten Buru. Bahan yang digunakan dalam penelitian ini adalah benih cabe rawit, dan EM4. Sedangkan alat-alat yang digunakan dalam penelitian ini adalah parang, cangkul, gembor, timbangan tali raffia, meteran, kamera, papan nama perlakuan, alat tulis, palu, paku, ember, gayung, dan alat lainnya yang dianggap perlu.

Penelitian ini dilakukan dengan menggunakan Rancangan Acak Kelompok (RAK)yang terdiri dari dua faktor yaitu : faktor jarak tanam dan pemberian EM4.

Faktor pertama adalah jarak tanam yang terdiri atas 3 taraf perlakuan yaitu : J1 $=40 \mathrm{~cm} \times 60 \mathrm{~cm}, \mathrm{~J} 2$ $=50 \mathrm{~cm} \times 60 \mathrm{~cm}, \mathrm{~J} 3=60 \mathrm{~cm} \times 60 \mathrm{~cm}$ kemudian Faktor kedua adalah EM4 yang terdiri atas 3 taraf perlakuan yaitu E0 = Tanpa EM4 (control), E1 = $150 \mathrm{Ltr} / \mathrm{Ha}, \mathrm{E} 2$ = $300 \mathrm{Ltr} / \mathrm{Ha}$. Pengamatan yang dilakukan pada penelitian ini meliputi parameter:

a. Tinggi tanaman diukur dari permukaan tanah sampai ujung daun tertinggi, pengukuran dilakukan setelah tanaman berumur 2 minggu setelah tanam, dan diukur 2 minggu sekali.

b. Jumlah cabang dihitung mulai dari pucuk yang sudah mengembang sempurna sampai daun terakhir paling bawah, perhitungan dilakukan bersama dengan pengukuran tinggi tanaman dan dihitung setiap 2 minggu sekali.

c. Jumlah bunga dihitung dari munculnya bunga, perhitungan dilakukan setiap 2 minggu sekali.

d. Jumlah buah dihitung munculnya bakal buah, perhitungan buah ini tidak bisa dihitung dari munculnya bunga karena semua bunga belum tentu menjadi bakal buah dan dilakukan setiap 2 minggu sekali.

e. Berat buah basah produksi penimbangan berat segar produksi dilakukan setelah panen dengan menimbang bagian tanaman khusunya buah.

Data pengamatan di analisis dengan mengunakan analisis sidik Ragam atau analisis of varance (ANOVA) dan jika menunjukan pengaruh yang Nyata maka di lanjutkan dengan uji Beda nyata Jujur ( BNJ ). (Hanafih, 2009).

\section{HASIL DAN PEMBAHASAN}

3.1. Hasil

\subsubsection{Tinggi Tanaman}

Tinggi tanaman pada umur 14, 28, 42 dan 56 HST dan sidik ragamnya disajikan pada Tabel 1, 2,3 dan 4 .

Tabel 1. Pengaruh sistim jarak tanam dan pemberian EM-4 terhadap tinggi tanaman cabai rawit umur 14 HST.

\begin{tabular}{cccccc}
\hline Perlakuan & $\mathrm{E}_{0}$ & $\mathrm{E}_{1}$ & $\mathrm{E}_{2}$ & Rataan & BNJ (0.05) \\
\hline $\mathrm{J}_{1}$ & $9.13^{\mathrm{a}}$ & $12.88^{\mathrm{b}}$ & $14.54^{\mathrm{bc}}$ & $12.18^{\mathrm{a}}$ & \\
$\mathrm{J}_{2}$ & $11.95^{\mathrm{b}}$ & $13.58^{\mathrm{bc}}$ & $15.78^{\mathrm{cd}}$ & $13.77^{\mathrm{ab}}$ & \multirow{2}{*}{2,68} \\
$\mathrm{~J}_{3}$ & $14.22^{\mathrm{bc}}$ & $14.22^{\mathrm{bc}}$ & $17.69^{\mathrm{d}}$ & $15.37^{\mathrm{b}}$ & \\
\hline Rataan & $11.77^{\mathrm{a}}$ & $13.56^{\mathrm{ab}}$ & $16.00^{\mathrm{b}}$ & & \\
\hline
\end{tabular}


Tabel 2. Pengaruh sistim jarak tanam dan pemberian EM-4 terhadap tinggi tanaman cabai rawit umur 28 HST.

\begin{tabular}{cccccc}
\hline Perlakuan & $\mathrm{E}_{0}$ & $\mathrm{E}_{1}$ & $\mathrm{E}_{2}$ & Rataan & BNJ (0.05) \\
\hline $\mathrm{J}_{1}$ & 20.54 & 23.48 & 27.06 & $23.69^{\mathrm{a}}$ & \\
$\mathrm{J}_{2}$ & 23.82 & 26.22 & 29.36 & $26.47^{\mathrm{b}}$ & \multirow{2}{*}{2,26} \\
$\mathrm{~J}_{3}$ & 25.58 & 27.36 & 32.22 & $28.39^{\mathrm{b}}$ & \\
\hline Rataan & $23.31^{\mathrm{a}}$ & $25.69^{\mathrm{b}}$ & $29.55^{\mathrm{c}}$ & & \\
\hline
\end{tabular}

Tabel 3. Pengaruh sistim jarak tanam dan pemberian EM-4 terhadap tinggi tanaman cabai rawit umur 42 HST.

\begin{tabular}{cccccc}
\hline Perlakuan & $\mathrm{E}_{0}$ & $\mathrm{E}_{1}$ & $\mathrm{E}_{2}$ & Rataan & BNJ (0.05) \\
\hline $\mathrm{J}_{1}$ & $31.60^{\mathrm{a}}$ & $43.33^{\mathrm{c}}$ & $46.19^{\mathrm{cd}}$ & $40.38^{\mathrm{a}}$ & \\
$\mathrm{J}_{2}$ & $36.60^{\mathrm{b}}$ & $45.23^{\mathrm{cd}}$ & $48.81^{\mathrm{d}}$ & $43.54^{\mathrm{ab}}$ & \multirow{3}{*}{3,40} \\
$\mathrm{~J}_{3}$ & $39.31^{\mathrm{b}}$ & $47.10^{\mathrm{cd}}$ & $53.50^{\mathrm{e}}$ & $46.64^{\mathrm{b}}$ & \\
\cline { 1 - 4 } Rataan & $35.84^{\mathrm{a}}$ & $45.22^{\mathrm{b}}$ & $49.50^{\mathrm{c}}$ & & \\
\hline
\end{tabular}

Tabel 4. Pengaruh sistim jarak tanam dan pemberian EM-4 terhadap tinggi tanaman cabai rawit umur 56 HST.

\begin{tabular}{cccccc}
\hline Perlakuan & E$_{0}$ & E1 $_{1}$ & E $_{2}$ & Rataan & BNJ (0.05) \\
\hline $\mathrm{J}_{1}$ & $50.62^{\mathrm{a}}$ & $66.33^{\mathrm{cd}}$ & $70.58^{\mathrm{de}}$ & $62.51^{\mathrm{a}}$ & \\
$\mathrm{J}_{2}$ & $57.41^{\mathrm{b}}$ & $70.93^{\mathrm{de}}$ & $76.03^{\mathrm{fg}}$ & $68.12^{\mathrm{b}}$ & \multirow{2}{*}{4,94} \\
$\mathrm{~J}_{3}$ & $62.25^{\mathrm{bcd}}$ & $74.94^{\text {ef }}$ & $80.30 \mathrm{~g}$ & $72.50^{\mathrm{b}}$ & \\
\hline Rataan & $56.76^{\mathrm{a}}$ & $70.73^{\mathrm{b}}$ & $75.64^{\mathrm{b}}$ & & \\
\cline { 1 - 3 }
\end{tabular}

Keterangan: Angka-angka yang dikuti oleh huruf yang berbeda berarti berbeda nyata pada taraf uji BNJ 0,05

\subsubsection{Jumlah Cabang}

Jumlah cabang tanaman cabai rawit pada umur 56 HST dan sidik ragamnya disajikan Tabel 5. Sidik ragam menunjukkan bahwa perlakuan jarak tanam (J) dan EM-4 (E) dan interaksinya (JE) berpengaruh sangat nyataPendugaan Model.

Tabel 5. Pengaruh jarak tanam dan pemberian EM-4 terhadap jumlah cabang tanaman cabai rawit umur 56 HST.

\begin{tabular}{cccccc}
\hline Perlakuan & $\mathrm{E}_{0}$ & $\mathrm{E}_{1}$ & $\mathrm{E}_{2}$ & Rataan & BNJ (0.05) \\
\hline $\mathrm{J}_{1}$ & $7.96^{\mathrm{a}}$ & $8.98^{\mathrm{ab}}$ & $9.79^{\mathrm{bc}}$ & $8.91^{\mathrm{a}}$ & \\
$\mathrm{J}_{2}$ & $9.17^{\mathrm{ab}}$ & $9.85^{\mathrm{bc}}$ & $12.32^{\mathrm{d}}$ & $10.45^{\mathrm{b}}$ & \multirow{2}{*}{1,29} \\
$\mathrm{~J}_{3}$ & $9.69^{\mathrm{bc}}$ & $10.63^{\mathrm{c}}$ & $14.01^{\mathrm{e}}$ & $11.45^{\mathrm{b}}$ & \\
\hline Rataan & $8.94^{\mathrm{a}}$ & $9.82^{\mathrm{a}}$ & $12.04^{\mathrm{b}}$ & & \\
\cline { 1 - 2 } Keterangan : & Angka-angka yang diikuti oleh huruf & yang berbeda berarti berbeda nyata pada \\
& taraf uji BNJ 0,05 & & &
\end{tabular}

Hasil uji BNJ pada Tabel 6 menunjukan bahwa perlakuan jarak tanam $60 \mathrm{~cm} \times 60 \mathrm{~cm}$ (J3) memberikan nilai rata-rata tertinggi untuk jumlah cabang tanaman cabai rawit umur 56 HST yaitu 11,45 cabang, berbeda tidak nyata dengan perlakuan jarak tanam $50 \mathrm{~cm} \times 50 \mathrm{~cm}$ (J2), tetapi berbeda nyata dengan perlakuan $\mathrm{J} 1(40 \mathrm{~cm} \times 60$ $\mathrm{cm})$. Perlakuan J2 dan J1 berbeda nyata.
Pemberian EM-4 dengan konsentrasi 300 1/ha (E2) memberikan nilai rata-rata tertinggi untuk jumlah cabang tanaman cabai rawit umur 56 HST yaitu 12,04 cabang, berbeda nyata dengan perlakuan E1 (150 L/ha) danperlakuan E0 (tanpa EM-4/kontrol). Perlakuan E1 dan E0 berbeda tidak nyata.

Interaksi antara jarak tanam $60 \mathrm{~cm} \times 60 \mathrm{~cm}$ dan EM-4 konsentarasi $300 \quad$ 1/ha $\quad$ (J3E2) 
memberikan jumlah cabang tanaman cabai rawit umur 56 HST yang terbaik yaitu 14,01 cabang berbeda nyata dengan kombinasi perlakuan jarak tanam dan EM-4 lainnya.

\subsubsection{Jumlah Bunga}

Jumlah bunga tanaman cabai rawit dan sidik ragamnya disajikan pada Tabel 6 . Sidik ragam menunjukkan bahwa perlakuan jarak tanam (J) dan EM-4 (E) berpengaruh sangat nyata sedangkan interaksinya (JE) berpengaruh tidak nyata.

Tabel 6. Pengaruh jarak tanam dan pemberian EM-4 terhadap jumlah bunga tanaman cabai rawit.

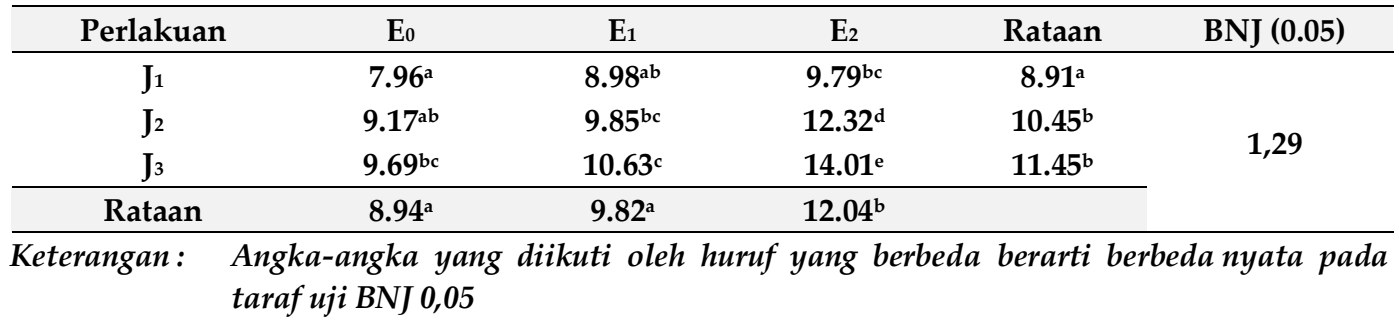

Hasil uji BNJ pada Tabel 6 menunjukan bahwa perlakuan jarak tanam $60 \mathrm{~cm} \times 60 \mathrm{~cm}(\mathrm{~J} 3)$ memberikan nilai rata-rata tertinggi untuk jumlah cabang tanaman cabai rawit umur 56 HST yaitu 11,45 cabang, berbeda tidak nyata dengan perlakuan jarak tanam $50 \mathrm{~cm} \times 50 \mathrm{~cm}$ (J2), tetapi berbeda nyata dengan perlakuan $\mathrm{J} 1(40 \mathrm{~cm} \times 60$ cm). Perlakuan J2 dan J1 berbeda nyata.

Pemberian EM-4 dengan konsentrasi 300 1/ha (E2) memberikan nilai rata-rata tertinggi untuk jumlah cabang tanaman cabai rawit umur 56 HST yaitu 12,04 cabang, berbeda nyata dengan perlakuan E1 (150 L/ha) danperlakuan E0 (tanpa EM-4/kontrol). Perlakuan E1 dan E0 berbeda tidak nyata.
Interaksi antara jarak tanam $60 \mathrm{~cm} \times 60 \mathrm{~cm}$ dan EM-4 konsentarasi 300 1/ha (J3E2) memberikan jumlah cabang tanaman cabai rawit umur 56 HST yang terbaik yaitu 14,01 cabang berbeda nyata dengan kombinasi perlakuan jarak tanam dan EM-4 lainnya.

\subsubsection{Jumlah Bunga}

Jumlah bunga tanaman cabai rawit dan sidik ragamnya disajikan pada Tabel 7. Sidik ragam menunjukkan bahwa perlakuan jarak tanam (J) dan EM-4 (E) berpengaruh sangat nyata sedangkan interaksinya (JE) berpengaruh tidak nyata.

Tabel 7. Pengaruh jarak tanam dan pemberian EM-4 terhadap jumlah bunga tanaman cabai rawit.

\begin{tabular}{|c|c|c|c|c|c|}
\hline Perlakuan & $\mathrm{E}_{0}$ & $E_{1}$ & $E_{2}$ & Rataan & BNJ (0.05) \\
\hline $\mathrm{J}_{1}$ & $7.96^{a}$ & $8.98^{\mathrm{ab}}$ & $9.79^{\mathrm{bc}}$ & $8.91^{\mathrm{a}}$ & \multirow{4}{*}{1,29} \\
\hline $\mathrm{J}_{2}$ & $9.17^{\mathrm{ab}}$ & $9.85^{\mathrm{bc}}$ & $12.32^{\mathrm{d}}$ & $10.45^{\mathrm{b}}$ & \\
\hline $\mathrm{J}_{3}$ & $9.69^{\mathrm{bc}}$ & $10.63^{c}$ & $14.01^{\mathrm{e}}$ & $11.45^{\mathrm{b}}$ & \\
\hline Rataan & $8.94^{\mathrm{a}}$ & $9.82^{a}$ & $12.04^{b}$ & & \\
\hline
\end{tabular}

Hasil uji BNJ pada Tabel 7menunjukan bahwa perlakuan jarak tanam $60 \mathrm{~cm}$ x $60 \mathrm{~cm}$ $\left(\mathrm{J}_{3}\right)$ memberikan nilai rata-rata tertinggi untuk jumlah cabang tanaman cabai rawit umur 56 HST yaitu 11,45 cabang, berbeda tidak nyata dengan perlakuan jarak tanam $50 \mathrm{~cm}$ x $50 \mathrm{~cm}$ $\left(\mathrm{J}_{2}\right)$, tetapi berbeda nyata dengan perlakuan $\mathrm{J}_{1}$
(40 $\mathrm{cm}$ x $60 \mathrm{~cm})$. Perlakuan $\mathrm{J}_{2}$ dan $\mathrm{J}_{1}$ berbeda nyata.

Pemberian $\mathrm{EM}_{-4}$ dengan konsentrasi 300 1/ha $\left(E_{2}\right)$ memberikan nilai rata-rata tertinggi untuk jumlah cabang tanaman cabai rawit umur 56 HST yaitu 12,04 cabang, berbeda nyata dengan perlakuan $\mathrm{E}_{1} \quad(150 \mathrm{~L} / \mathrm{ha})$ 
danperlakuan $\mathrm{E}_{0} \quad$ (tanpa $\quad \mathrm{EM}_{4} /$ kontrol). Perlakuan $\mathrm{E}_{1}$ dan $\mathrm{E}_{0}$ berbeda tidak nyata.

Interaksi antara jarak tanam $60 \mathrm{~cm} \times 60$ $\mathrm{cm}$ dan $\mathrm{EM}_{-4}$ konsentarasi 300 1/ha $\left(\mathrm{J}_{3} \mathrm{E}_{2}\right)$ memberikan jumlah cabang tanaman cabai rawit umur 56 HST yang terbaik yaitu 14,01 cabang berbeda nyata dengan kombinasi perlakuan jarak tanam dan $\mathrm{EM}_{-4}$ lainnya.

\subsubsection{Jumlah Buah}

Jumlah buah tanaman cabai rawit panen I dan sidik ragamnya disajikan pada Tabel 8. Sidik ragam menunjukkan bahwa perlakuan jarak tanam (J) dan $\mathrm{EM}_{-4}$ (E) berpengaruh sangat nyata sedangkan interaksinya (JE) berpengaruh nyata.

Tabel 8. Pengaruh jarak tanam dan pemberian EM-4 terhadap jumlah buah panen I tanaman cabai rawit.

\begin{tabular}{|c|c|c|c|c|c|}
\hline Perlakuan & $E_{0}$ & $E_{1}$ & $E_{2}$ & Rataan & BNJ (0.05) \\
\hline $\mathbf{J}_{1}$ & $99.48^{a}$ & $101.43^{\mathrm{ab}}$ & $108.20^{\mathrm{abc}}$ & $103.04^{a}$ & \multirow{4}{*}{41,16} \\
\hline $\mathbf{J}_{2}$ & $111.98^{a b c}$ & $145.18^{\mathrm{cd}}$ & $176.51^{\text {de }}$ & $144.56^{b}$ & \\
\hline $\mathbf{J}_{3}$ & $122.23^{a b c}$ & $140.58^{\mathrm{bcd}}$ & $192.45^{\mathrm{e}}$ & $151.75^{b}$ & \\
\hline Rataan & $111.23^{a}$ & $129.06^{\mathrm{ab}}$ & $159.05^{b}$ & & \\
\hline
\end{tabular}

Hasil uji BNJ pada Tabel 8 menunjukan bahwa perlakuan jarak tanam $60 \mathrm{~cm} \times 60 \mathrm{~cm}$ (J3) memberikan nilai rata-rata tertinggi untuk jumlah buah tanaman cabai rawit panen I yaitu 151,75 buah, berbeda tidak nyata dengan perlakuan jarak tanam $50 \mathrm{~cm} \times 50 \mathrm{~cm}(\mathrm{~J} 2)$, tetapi berbeda nyata dengan perlakuan $\mathrm{J} 1(40 \mathrm{~cm} \times 60$ cm). Perlakuan J2 dan J1 berbeda nyata.

Pemberian EM-4 dengan konsentrasi 300 1/ha (E2) memberikan nilai rata-rata tertinggi untuk jumlah buah tanaman cabai rawit panen Iyaitu 159,05 buah, berbeda tidak nyata dengan perlakuan E1 (150 L/ha), tetapi berbeda nyata dengan perlakuan E0 (tanpa EM-4/kontrol). Perlakuan E1 dan E0 berbeda tidak nyata.

Interaksi antara jarak tanam $60 \mathrm{~cm} \times 60 \mathrm{~cm}$ dan EM-4 konsentarasi $300 \quad$ 1/ha (J3E2) memberikan jumlah buah terbanyak tanaman cabai rawit panen I yaitu 192,45 buah berbeda tidak nyata dengan perlakuan J2E2, tetapi berbeda nyata dengan kombinasi perlakuan lainnya.

Jumlah buah tanaman cabai rawit panen II dan sidik ragamnya disajikan pada Tabel 9. Sidik ragam menunjukkan bahwa perlakuan jarak tanam (J) dan EM-4 (E) berpengaruh sangat nyata sedangkan interaksinya (JE) berpengaruh nyata.

Tabel 9. Pengaruh jarak tanam dan pemberian EM-4 terhadap jumlah buah panen II tanaman cabai rawit.

\begin{tabular}{cccccc}
\hline Perlakuan & $\mathrm{E}_{0}$ & $\mathrm{E}_{1}$ & $\mathrm{E}_{2}$ & Rataan & BNJ (0.05) \\
\cline { 1 - 4 } $\mathrm{J}_{1}$ & $127.01^{\mathrm{a}}$ & $144.98^{\mathrm{ab}}$ & $176.51^{\mathrm{bcd}}$ & $149.50^{\mathrm{a}}$ & \\
$\mathrm{J}_{2}$ & $151.87^{\mathrm{abc}}$ & $197.45^{\mathrm{de}}$ & $246.92^{\mathrm{fg}}$ & $198.75^{\mathrm{b}}$ & \multirow{2}{*}{40,39} \\
$\mathrm{~J}_{3}$ & $187.78^{\mathrm{cde}}$ & $208.04^{\mathrm{ef}}$ & $277.61^{\mathrm{g}}$ & $224.48^{\mathrm{b}}$ & \\
\hline Rataan & $155.55^{\mathrm{a}}$ & $183.49^{\mathrm{ab}}$ & $233.68^{\mathrm{b}}$ & & \\
\cline { 1 - 2 } Keterangan : & Angka-angka yang & diikuti oleh huruf yang berbeda berarti berbeda nyata pada \\
& taraf uji BNJ 0,05 & & &
\end{tabular}

Hasil uji BNJ pada Tabel 9 menunjukan bahwa perlakuan jarak tanam $60 \mathrm{~cm} \times 60 \mathrm{~cm}(\mathrm{~J} 3)$ memberikan nilai rata-rata tertinggi untuk jumlah buah tanaman cabai rawit panen II yaitu 224,48 buah, berbeda tidak nyata dengan perlakuan jarak tanam $50 \mathrm{~cm} \times 50 \mathrm{~cm}(\mathrm{~J} 2)$, tetapi berbeda nyata dengan perlakuan J1 $(40 \mathrm{~cm}$ x 60 $\mathrm{cm})$. Perlakuan J2 dan J1 berbeda nyata.

Pemberian EM-4 dengan konsentrasi 300 1/ha (E2) memberikan nilai rata-rata tertinggi untuk jumlah buah tanaman cabai rawit panen II yaitu 233,68 buah, berbeda tidak nyata dengan 
perlakuan E1 (150 L/ha), tetapi berbeda nyata dengan perlakuan E0 (tanpa EM-4/kontrol). Perlakuan E1 dan E0 berbeda tidak nyata.

Interaksi antara jarak tanam $60 \mathrm{~cm} \times 60 \mathrm{~cm}$

dan EM-4 konsentarasi 300 1/ha (J3E2) memberikan jumlah buah terbanyak tanaman cabai rawit panen II yaitu 277,61 buah berbeda tidak nyata dengan perlakuan J2E2, tetapi berbeda nyata dengan kombinasi perlakuan lainnya.

Jumlah buah tanaman cabai rawit panen III dan sidik ragamnya disajikan pada Tabel 10. Sidik ragam menunjukkan bahwa perlakuan jarak tanam (J) dan EM-4 (E) berpengaruh sangat nyata sedangkan interaksinya (JE) berpengaruh tidak nyata.

Tabel 10. Pengaruh jarak tanam dan pemberian EM-4 terhadap jumlah buah panen III tanaman cabai rawit.

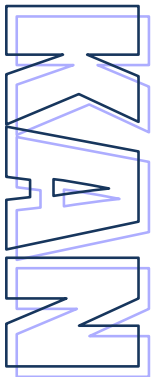

\begin{tabular}{|c|c|c|c|c|c|}
\hline Perlakuan & $\mathrm{E}_{0}$ & $\mathrm{E}_{1}$ & $\mathrm{E}_{2}$ & Rataan & BNJ (0.05) \\
\hline $\mathrm{J}_{1}$ & 154.30 & 165.66 & 184.33 & $168.10^{a}$ & \multirow{4}{*}{48,41} \\
\hline $\mathrm{J}_{2}$ & 174.52 & 205.89 & 246.92 & $209.11^{\mathrm{ab}}$ & \\
\hline $\mathrm{J}_{3}$ & 211.35 & 223.23 & 285.59 & $240.06^{b}$ & \\
\hline Rataan & $180.05^{a}$ & $198.26^{\mathrm{ab}}$ & $238.95^{b}$ & & \\
\hline
\end{tabular}

Keterangan: Angka-angka yang diikuti oleh huruf yang berbeda berarti berbeda nyata pada taraf uji BNJ 0,05

Hasil uji BNJ pada Tabel 10 menunjukan bahwa perlakuan jarak tanam $60 \mathrm{~cm} \times 60 \mathrm{~cm}$ (J3) memberikan nilai rata-rata tertinggi untuk jumlah buah tanaman cabai rawit panen III yaitu 240 buah, berbeda tidak nyata dengan perlakuan jarak tanam $50 \mathrm{~cm} \times 50 \mathrm{~cm}(\mathrm{~J} 2)$, tetapi berbeda nyata dengan perlakuan $\mathrm{J} 1(40 \mathrm{~cm} \times 60 \mathrm{~cm})$. Perlakuan J2 dan J1 berbeda nyata.

Pemberian EM-4 dengan konsentrasi 300 1/ha (E2) memberikan nilai rata-rata tertinggi untuk jumlah buah tanaman cabai rawit panen
III yaitu 238,95 buah, berbeda tidak nyata dengan perlakuan E1 (150 L/ha), tetapi berbeda nyata dengan perlakuan E0 (tanpa EM-4/kontrol). Perlakuan E1 dan E0 berbeda tidak nyata.

\subsubsection{Berat Buah Per Tanaman}

Berat buah tanaman cabai rawit panen I dan sidik ragamnya disajikan pada Tabel 11. Sidik ragam menunjukkan bahwa perlakuan jarak tanam (J) dan EM-4 (E) serta interaksinya berpengaruh sangat nyata.

Tabel 11. Pengaruh jarak tanam dan pemberian EM-4 terhadap berat buah panen I tanaman cabai rawit.

\begin{tabular}{cccccc}
\hline Perlakuan & $\mathrm{E}_{0}$ & $\mathrm{E}_{1}$ & $\mathrm{E}_{2}$ & Rataan & BNJ (0.05) \\
\cline { 1 - 4 } $\mathrm{J}_{1}$ & 150.65 & 156.21 & 164.90 & $157.25^{\mathrm{a}}$ & \\
$\mathrm{J}_{2}$ & 160.10 & 174.78 & 230.78 & $188.55^{\mathrm{b}}$ & \multirow{2}{*}{16,40} \\
$\mathrm{~J}_{3}$ & 182.04 & 189.59 & 286.89 & $219.51^{\mathrm{c}}$ & \\
\hline Rataan & $164.26^{\mathrm{a}}$ & $173.53^{\mathrm{a}}$ & $227.52^{\mathrm{b}}$ & & \\
\cline { 1 - 3 } Keterangan: & Angka-angka yang & diikuti oleh huruf yang berbeda & berarti berbeda nyata pada \\
& taraf uji BNJ 0,05 & & &
\end{tabular}

Hasil uji BNJ pada Tabel 11 menunjukan bahwa perlakuan jarak tanam $60 \mathrm{~cm} \times 60 \mathrm{~cm}(\mathrm{~J} 3)$ memberikan nilai rata-rata tertinggi untuk berat buah tanaman cabai rawit panen I yaitu 219,51 gram, berbedanyata dengan perlakuan jarak tanam $50 \mathrm{~cm} \times 50 \mathrm{~cm}$ (J2)dan perlakuan J1 $(40 \mathrm{~cm} \times$ $60 \mathrm{~cm})$. Perlakuan J2 dan J1 berbeda nyata.
Pemberian EM-4 dengan konsentrasi 300 1/ha (E2) memberikan nilai rata-rata tertinggi untuk berat buah tanaman cabai rawit panen $I$ yaitu 227,52 gram, berbedanyata dengan perlakuan E1 (150 L/ha)dan perlakuan E0 (tanpa EM-4/kontrol). Perlakuan E1 dan E0 berbeda tidak nyata. 
Berat buah tanaman cabai rawit panen II jarak tanam (J) dan EM-4 (E) serta interaksinya dan sidik ragamnya disajikan pada Tabel 12 . berpengaruh sangat nyata.

Sidik ragam menunjukkan bahwa perlakuan

Tabel 12. Pengaruh jarak tanam dan pemberian EM-4 terhadap berat buah panen II tanaman cabai rawit.

\begin{tabular}{cccccc}
\hline Perlakuan & $\mathrm{E}_{0}$ & $\mathrm{E}_{1}$ & $\mathrm{E}_{2}$ & Rataan & BNJ (0.05) \\
\cline { 1 - 5 } $\mathrm{J}_{1}$ & $152.39^{\mathrm{a}}$ & $163.52^{\mathrm{a}}$ & $174.78^{\mathrm{ab}}$ & $163.56^{\mathrm{a}}$ & \\
$\mathrm{J}_{2}$ & $165.51^{\mathrm{a}}$ & $188.86^{\mathrm{ab}}$ & $250.21^{\mathrm{c}}$ & $201.53^{\mathrm{ab}}$ & \multirow{2}{*}{43,25} \\
$\mathrm{~J}_{3}$ & $182.37^{\mathrm{ab}}$ & $213.61^{\mathrm{bc}}$ & $300.66^{\mathrm{d}}$ & $232.22^{\mathrm{b}}$ & \\
\cline { 1 - 5 } Rataan & $166.76^{\mathrm{a}}$ & $188.66^{\mathrm{ab}}$ & $241.88^{\mathrm{b}}$ & & \\
\cline { 1 - 4 } & & &
\end{tabular}

Keterangan: Angka-angka yang diikuti oleh huruf yang berbeda berarti berbeda nyata pada taraf uji BNJ 0,05

Hasil uji BNJ pada Tabel 12 menunjukan bahwa perlakuan jarak tanam $60 \mathrm{~cm} \times 60 \mathrm{~cm}(\mathrm{~J} 3)$ memberikan nilai rata-rata tertinggi untuk berat buah tanaman cabai rawit panen IIyaitu 232,22 gram, berbedatidak nyata dengan perlakuan jarak tanam $50 \mathrm{~cm} \times 50 \mathrm{~cm}$ (J2), tetapi berbeda nyata dengan perlakuan $\mathrm{J} 1(40 \mathrm{~cm} \times 60 \mathrm{~cm})$. Perlakuan J2 dan J1 berbeda tidak nyata.

Pemberian EM-4 dengan konsentrasi 300 1/ha (E2) memberikan nilai rata-rata tertinggi untuk berat buah tanaman cabai rawit panen IIyaitu 241,88 gram, berbedatidak nyata dengan perlakuan E1 (150 L/ha)tetapi berbeda nyata dengan perlakuan E0 (tanpa EM-4/kontrol). Perlakuan E1 dan E0 berbeda tidak nyata.

Interaksi antara jarak tanam $60 \mathrm{~cm} \times 60 \mathrm{~cm}$ dan EM-4 konsentarasi $300 \quad$ 1/ha (J3E2) memberikan berat buah tertinggi tanaman cabai rawit panen II yaitu 300,66 buah berbeda nyata dengan semua kombinasi perlakuan lainnya.

Berat buah tanaman cabai rawit panen III dan sidik ragamnya disajikan pada Tabel 13. Sidik ragam menunjukkan bahwa perlakuan jarak tanam (J) dan EM-4 (E) serta interaksinya berpengaruh sangat nyata.

Tabel 13. Pengaruh jarak tanam dan pemberian EM-4 terhadap berat buah panen III tanaman cabai rawit.

\begin{tabular}{cccccc}
\hline Perlakuan & $\mathrm{E}_{0}$ & $\mathrm{E}_{1}$ & $\mathrm{E}_{2}$ & Rataan & BNJ (0.05) \\
\hline $\mathrm{J}_{1}$ & $125.85^{\mathrm{a}}$ & $135.83^{\mathrm{a}}$ & $177.62^{\mathrm{bc}}$ & $146.44^{\mathrm{a}}$ & \\
$\mathrm{J}_{2}$ & $153.80^{\mathrm{ab}}$ & $191.88^{\mathrm{cd}}$ & $250.65^{\mathrm{e}}$ & $198.78^{\mathrm{b}}$ & 36,60 \\
$\mathrm{~J}_{3}$ & $172.74^{\mathrm{bc}}$ & $227.33^{\mathrm{de}}$ & $332.05^{\mathrm{f}}$ & $244.04^{\mathrm{c}}$ & \\
\hline Rataan & $150.80^{\mathrm{a}}$ & $185.02^{\mathrm{a}}$ & $253.44^{\mathrm{b}}$ & & \\
\hline Keterangan : & Angka-angka yang diikuti oleh huruf yang berbeda berarti berbeda nyata pada taraf uji & &
\end{tabular}

Hasil uji BNJ pada Tabel 13 menunjukan bahwa perlakuan jarak tanam $60 \mathrm{~cm} \times 60 \mathrm{~cm}$ (J3) memberikan nilai rata-rata tertinggi untuk berat buah tanamancabai rawit panen II yaitu 244,04 gram, berbedanyata dengan perlakuan jarak tanam $50 \mathrm{~cm} \times 50 \mathrm{~cm}$ (J2)dan perlakuan $\mathrm{J1}(40 \mathrm{~cm} \times$ $60 \mathrm{~cm}$ ). Perlakuan J2 dan J1 berbeda nyata.

Pemberian EM-4 dengan konsentrasi 300 1/ha (E2) memberikan nilai rata-rata tertinggi untuk berat buah tanaman cabai rawit panen II yaitu 253,44 gram, berbedanyata dengan perlakuan E1 (150 L/ha) dan perlakuan E0 (tanpa
EM-4/kontrol). Perlakuan E1 dan E0 berbeda tidak nyata.

Interaksi antara jarak tanam $60 \mathrm{~cm} \times 60 \mathrm{~cm}$ dan EM-4 konsentarasi $300 \quad$ 1/ha $\quad$ (J3E2) memberikan berat buah tertinggi tanaman cabai rawit panen II yaitu 332,05 buah berbeda nyata dengan semua kombinasi perlakuan lainnya.

\subsubsection{Berat Buah Per Petak}

Berat buah per petak tanaman cabai rawit panen I dan sidik ragamnya disajikan pada Tabel 14. Sidik ragam menunjukkan bahwa perlakuan 
jarak tanam (J) dan EM-4 (E) serta interaksinya berpengaruh sangat nyata.

Tabel 14. Pengaruh jarak tanam dan pemberian EM-4 terhadap berat buah per petak panen I tanaman cabai rawit.

\begin{tabular}{cccccc}
\hline Perlakuan & $\mathrm{E}_{0}$ & $\mathrm{E}_{1}$ & $\mathrm{E}_{2}$ & Rataan & BNJ (0.05) \\
\cline { 1 - 4 } $\mathrm{J}_{1}$ & $3.01^{\mathrm{a}}$ & $3.12^{\mathrm{a}}$ & $3.30^{\mathrm{ab}}$ & $3.14^{\mathrm{a}}$ & \\
$\mathrm{J}_{2}$ & $3.20^{\mathrm{ab}}$ & $3.50^{\mathrm{bc}}$ & $4.61^{\mathrm{d}}$ & $3.77^{\mathrm{b}}$ & \multirow{2}{*}{0,33} \\
$\mathrm{~J}_{3}$ & $3.64^{\mathrm{c}}$ & $3.79^{\mathrm{c}}$ & $5.74^{\mathrm{e}}$ & $4.39^{\mathrm{c}}$ & \\
\hline Rataan & $3.29^{\mathrm{a}}$ & $3.47^{\mathrm{a}}$ & $4.55^{\mathrm{b}}$ & & \\
\cline { 1 - 2 } Keterangan: & Angka-angka yang diikuti oleh huruf yang berbeda & berarti berbeda nyata pada \\
& taraf uji BNJ 0,05 & & &
\end{tabular}

Hasil uji BNJ pada Tabel 14 menunjukan bahwa perlakuan jarak tanam $60 \mathrm{~cm} \times 60 \mathrm{~cm}\left(\mathrm{~J}_{3}\right)$ memberikan nilai rata-rata tertinggi untuk berat buah per petaktanaman cabai rawit panen I yaitu $4,39 \mathrm{~kg}$, berbedanyata dengan perlakuan jarak tanam $50 \mathrm{~cm} \times 50 \mathrm{~cm}\left(\mathrm{~J}_{2}\right)$ dan perlakuan $\mathrm{J}_{1}(40 \mathrm{~cm} \times$ $60 \mathrm{~cm})$. Perlakuan $\mathrm{J}_{2}$ dan $\mathrm{J}_{1}$ berbeda nyata.

Pemberian EM-4 dengan konsentrasi 300 1/ha $\left(E_{2}\right)$ memberikan nilai rata-rata tertinggi untuk berat buah per petak tanaman cabai rawit panen I yaitu $4,55 \mathrm{~kg}$, berbedanyata dengan perlakuan $E_{1}(150 \mathrm{~L} / \mathrm{ha})$ dan perlakuan $E_{0}$ (tanpa
EM-4/kontrol). Perlakuan E1 dan Eo berbeda tidak nyata.

Interaksi antara jarak tanam $60 \mathrm{~cm} \times 60 \mathrm{~cm}$ dan $\quad$ EM-4 konsentarasi $300 \quad 1 / h a \quad\left(J_{3} E_{2}\right)$ memberikan berat buah per petak tertinggi tanaman cabai rawit panen I yaitu $5,74 \mathrm{~kg}$ berbeda nyata dengan semua kombinasi perlakuan lainnya.

Berat buah per petak tanaman cabai rawit panen II dan sidik ragamnya disajikan pada Tabel 15. Sidik ragam menunjukkan bahwa perlakuan jarak tanam (J) dan EM-4 (E) serta interaksinya berpengaruh sangat nyata.

Tabel 15. Pengaruh jarak tanam dan pemberian EM-4 terhadap berat buah per petak panen II tanaman cabai rawit.

\begin{tabular}{cccccc}
\hline Perlakuan & $\mathrm{E}_{0}$ & $\mathrm{E}_{1}$ & $\mathrm{E}_{2}$ & Rataan & BNJ (0.05) \\
\cline { 1 - 4 } $\mathrm{J}_{1}$ & $3.05^{\mathrm{a}}$ & $3.27^{\mathrm{a}}$ & $3.50^{\mathrm{ab}}$ & $3.27^{\mathrm{a}}$ & \\
$\mathrm{J}_{2}$ & $3.31^{\mathrm{a}}$ & $3.78^{\mathrm{abc}}$ & $5.00^{\mathrm{d}}$ & $4.03^{\mathrm{ab}}$ & \multirow{2}{*}{0,87} \\
$\mathrm{~J}_{3}$ & $3.65^{\mathrm{abc}}$ & $4.27^{\mathrm{bcd}}$ & $6.01^{\mathrm{e}}$ & $4.64^{\mathrm{b}}$ & \\
\cline { 1 - 4 } Rataan & $3.34^{\mathrm{a}}$ & $3.77^{\mathrm{a}}$ & $4.84^{\mathrm{b}}$ & & \\
\cline { 1 - 4 }
\end{tabular}

Keterangan: Angka-angka yang diikuti oleh huruf yang berbeda berarti berbeda nyata pada taraf uji BNJ 0,05

Hasil uji BNJ pada Tabel 15 menunjukan bahwa perlakuan jarak tanam $60 \mathrm{~cm} \times 60 \mathrm{~cm}\left(\mathrm{~J}_{3}\right)$ memberikan nilai rata-rata tertinggi untuk berat buah per petak tanaman cabai rawit panen II yaitu 4,46 kg, berbeda tidak nyata dengan perlakuan jarak tanam $50 \mathrm{~cm} \times 50 \mathrm{~cm}\left(\mathrm{~J}_{2}\right)$, tetapi berbeda nyata dengan perlakuan $\mathrm{J}_{1}(40 \mathrm{~cm} \times 60$ $\mathrm{cm})$. Perlakuan $\mathrm{J}_{2}$ dan $\mathrm{J}_{1}$ berbeda nyata.

Pemberian EM-4 dengan konsentrasi 300 1/ha $\left(E_{2}\right)$ memberikan nilai rata-rata tertinggi untuk berat buah per petak tanaman cabai rawit panen II yaitu $4,84 \mathrm{~kg}$, berbedanyata dengan perlakuan $E_{1}(150 \mathrm{~L} / \mathrm{ha})$ dan perlakuan $\mathrm{E}_{0}$ (tanpa
EM-4/kontrol). Perlakuan E1 dan E 0 berbeda tidak nyata.

Interaksi antara jarak tanam $60 \mathrm{~cm} \times 60 \mathrm{~cm}$ dan EM-4 konsentarasi $300 \quad 1 / \mathrm{ha} \quad\left(\mathrm{J}_{3} \mathrm{E}_{2}\right)$ memberikan berat buah per petak tertinggi tanaman cabai rawit panen II yaitu 6,01 kg berbeda nyata dengan semua kombinasi perlakuan lainnya.

Berat buah per petak tanaman cabai rawit panen III dan sidik ragamnya disajikan pada Tabel 16. Sidik ragam menunjukkan bahwa perlakuan jarak tanam (J) dan EM-4 (E) serta interaksinya berpengaruh sangat nyata. 
Tabel 16. Pengaruh jarak tanam dan pemberian EM-4 terhadap berat buah per petak panen III tanaman cabai rawit.

\begin{tabular}{cccccc}
\hline Perlakuan & $\mathrm{E}_{0}$ & $\mathrm{E}_{1}$ & $\mathrm{E}_{2}$ & Rataan & BNJ (0.05) \\
\hline $\mathrm{J}_{1}$ & $2.52^{\mathrm{a}}$ & $2.71^{\mathrm{a}}$ & $3.55^{\mathrm{bc}}$ & $2.93^{\mathrm{a}}$ & \\
$\mathrm{J}_{2}$ & $3.08^{\mathrm{ab}}$ & $3.84^{\mathrm{cd}}$ & $5.01^{\mathrm{d}}$ & $3.98^{\mathrm{b}}$ & \multirow{2}{*}{0,73} \\
$\mathrm{~J}_{3}$ & $3.46^{\mathrm{bc}}$ & $4.55^{\mathrm{d}}$ & $6.64^{\mathrm{e}}$ & $4.88^{\mathrm{c}}$ & \\
\hline Rataan & $3.02^{\mathrm{a}}$ & $3.70^{\mathrm{a}}$ & $5.07^{\mathrm{b}}$ & & \\
\cline { 1 - 2 } Keterangan : Angka-angka yang diikuti oleh huruf yang berbeda berarti berbeda nyata pada taraf & &
\end{tabular}

Hasil uji BNJ pada Tabel 16menunjukan bahwa perlakuan jarak tanam $60 \mathrm{~cm} \times 60 \mathrm{~cm}\left(\mathrm{~J}_{3}\right)$ memberikan nilai rata-rata tertinggi untuk berat buah per petak tanaman cabai rawit panen III yaitu $4,88 \mathrm{~kg}$, berbedanyata dengan perlakuan jarak tanam $50 \mathrm{~cm} \times 50 \mathrm{~cm}\left(\mathrm{~J}_{2}\right)$ dan perlakuan $\mathrm{J}_{1}(40$ $\mathrm{cm} \times 60 \mathrm{~cm}$ ). Perlakuan $\mathrm{J}_{2}$ dan $\mathrm{J}_{1}$ berbeda nyata.

Pemberian EM-4 dengan konsentrasi 300 1/ha $\left(E_{2}\right)$ memberikan nilai rata-rata tertinggi untuk berat buah per petak tanaman cabai rawit panen III yaitu $5,07 \mathrm{~kg}$, berbedanyata dengan perlakuan $E_{1}(150 \mathrm{~L} / \mathrm{ha})$ dan perlakuan $\mathrm{E}_{0}$ (tanpa EM-4/kontrol). Perlakuan E1 dan E 0 berbeda tidak nyata.
Interaksi antara jarak tanam $60 \mathrm{~cm} \times 60 \mathrm{~cm}$ dan EM-4 konsentarasi $300 \quad 1 / \mathrm{ha} \quad\left(\mathrm{J}_{3} \mathrm{E}_{2}\right)$ memberikan berat buah per petak tertinggi tanaman cabai rawit panen III yaitu $6,64 \mathrm{~kg}$ berbeda nyata dengan semua kombinasi perlakuan lainnya.

\subsubsection{Berat Buah Per Hektar.}

Berat buah per hektar tanaman cabai rawit panen I dan sidik ragamnya disajikan pada Tabel 17. Sidik ragam menunjukkan bahwa perlakuan jarak tanam (J) dan EM-4 (E) serta interaksinya berpengaruh sangat nyata.

Tabel 17. Pengaruh jarak tanam dan pemberian EM-4 terhadap berat buah per hektar panen I tanaman cabai rawit.

\begin{tabular}{cccccc}
\hline Perlakuan & $\mathrm{E}_{0}$ & $\mathrm{E}_{1}$ & $\mathrm{E}_{2}$ & Rataan & BNJ (0.05) \\
\cline { 1 - 4 } $\mathrm{J}_{1}$ & $5.02^{\mathrm{a}}$ & $5.20^{\mathrm{a}}$ & $5.49^{\mathrm{ab}}$ & $5.24^{\mathrm{a}}$ & \\
$\mathrm{J}_{2}$ & $5.34^{\mathrm{ab}}$ & $5.83^{\mathrm{bc}}$ & $7.69^{\mathrm{d}}$ & $6.29^{\mathrm{b}}$ & \multirow{2}{*}{0,55} \\
$\mathrm{~J}_{3}$ & $6.07^{\mathrm{c}}$ & $6.32^{\mathrm{c}}$ & $9.57^{\mathrm{e}}$ & $7.32^{\mathrm{c}}$ & \\
\cline { 1 - 4 } Rataan & $5.48^{\mathrm{a}}$ & $5.78^{\mathrm{a}}$ & $7.58^{\mathrm{b}}$ & & \\
\hline
\end{tabular}

Keterangan: Angka-angka yang diikuti oleh huruf yang berbeda berarti berbeda nyata pada taraf uji BNJ 0,05

Hasil uji BNJ pada Tabel 17menunjukan bahwa perlakuan jarak tanam $60 \mathrm{~cm} \times 60 \mathrm{~cm}\left(\mathrm{~J}_{3}\right)$ memberikan nilai rata-rata tertinggi untuk berat buah per hektar tanaman cabai rawit panen I yaitu 7,32 ton, berbedanyata dengan perlakuan jarak tanam $50 \mathrm{~cm} \times 50 \mathrm{~cm}\left(\mathrm{~J}_{2}\right)$ dan perlakuan $\mathrm{J}_{1}(40$ $\mathrm{cm} \times 60 \mathrm{~cm}$ ). Perlakuan $\mathrm{J}_{2}$ dan $\mathrm{J}_{1}$ berbeda nyata.

Pemberian EM-4 dengan konsentrasi 300 1/ha $\left(E_{2}\right)$ memberikan nilai rata-rata tertinggi untuk berat buah per hektar tanaman cabai rawit panen I yaitu 7,58 ton, berbedanyata dengan perlakuan $E_{1}(150 \mathrm{~L} / \mathrm{ha})$ dan perlakuan $\mathrm{E}_{0}(\operatorname{tanpa}$
EM-4/kontrol). Perlakuan E1 dan Eo berbeda tidak nyata.

Interaksi antara jarak tanam $60 \mathrm{~cm} \times 60 \mathrm{~cm}$ dan EM-4 konsentarasi $300 \quad$ 1/ha $\quad\left(J_{3} E_{2}\right)$ memberikan berat buah per hektar tertinggi tanaman cabai rawit panen I yaitu 9,57 ton berbeda nyata dengan semua kombinasi perlakuan lainnya.

Berat buah per hektar tanaman cabai rawit panen II dan sidik ragamnya disajikan pada Tabel 18. Sidik ragam menunjukkan bahwa perlakuan jarak tanam (J) dan EM-4 (E) serta interaksinya berpengaruh sangat nyata. 
Tabel 18. Pengaruh jarak tanam dan pemberian EM-4 terhadap berat buah per hektar panen II tanaman cabai rawit.

\begin{tabular}{cccccc}
\hline Perlakuan & $\mathrm{E}_{0}$ & $\mathrm{E}_{1}$ & $\mathrm{E}_{2}$ & Rataan & BNJ (0.05) \\
\hline $\mathrm{J}_{1}$ & $5.08^{\mathrm{a}}$ & $5.45^{\mathrm{a}}$ & $5.83^{\mathrm{a}}$ & $5.45^{\mathrm{a}}$ & \\
$\mathrm{J}_{2}$ & $5.52^{\mathrm{a}}$ & $6.29^{\mathrm{ab}}$ & $8.34^{\mathrm{c}}$ & $6.72^{\mathrm{ab}}$ & \multirow{2}{*}{1,44} \\
$\mathrm{~J}_{3}$ & $6.08^{\mathrm{ab}}$ & $7.12^{\mathrm{bc}}$ & $10.02^{\mathrm{d}}$ & $7.74^{\mathrm{b}}$ & \\
\cline { 1 - 4 } Rataan & $5.56^{\mathrm{a}}$ & $6.29^{\mathrm{a}}$ & $8.06^{\mathrm{b}}$ & & \\
\hline
\end{tabular}

Keterangan: Angka-angka yang diikuti oleh huruf yang berbeda berarti berbeda nyata pada taraf uji BNJ 0,05

Hasil uji BNJ pada Tabel 18 menunjukan bahwa perlakuan jarak tanam $60 \mathrm{~cm} \times 60 \mathrm{~cm}\left(\mathrm{~J}_{3}\right)$ memberikan nilai rata-rata tertinggi untuk berat buah per hektar tanaman cabai rawit panen II yaitu 7,74 ton, berbedanyata dengan perlakuan jarak tanam $50 \mathrm{~cm} \times 50 \mathrm{~cm}\left(\mathrm{~J}_{2}\right)$ dan perlakuan $\mathrm{J}_{1}(40$ $\mathrm{cm} \times 60 \mathrm{~cm}$ ). Perlakuan $\mathrm{J}_{2}$ dan $\mathrm{J}_{1}$ berbeda tidak nyata.

Pemberian EM-4 dengan konsentrasi 300 1/ha $\left(E_{2}\right)$ memberikan nilai rata-rata tertinggi untuk berat buah per hektar tanaman cabai rawit panen II yaitu 8,06ton, berbedanyata dengan perlakuan $E_{1}(150 \mathrm{~L} / \mathrm{ha})$ dan perlakuan $\mathrm{E}_{0}(\operatorname{tanpa}$
EM-4/kontrol). Perlakuan E1 dan Eo berbeda tidak nyata.

Interaksi antara jarak tanam $60 \mathrm{~cm} \times 60 \mathrm{~cm}$ dan EM-4 konsentarasi $300 \quad$ 1/ha $\quad\left(\mathrm{J}_{3} \mathrm{E}_{2}\right)$ memberikan berat buah per hektar tertinggi tanaman cabai rawit panen II yaitu 10,02 ton berbeda nyata dengan semua kombinasi perlakuan lainnya.

Berat buah per hektar tanaman cabai rawit panen III dan sidik ragamnya disajikan pada Tabel 19. Sidik ragam menunjukkan bahwa perlakuan jarak tanam (J) dan EM-4 (E) serta interaksinya berpengaruh sangat nyata.

Tabel 19. Pengaruh jarak tanam dan pemberian EM-4 terhadap berat buah per hektar panen III tanaman cabai rawit.

\begin{tabular}{cccccc}
\hline Perlakuan & $\mathrm{E}_{0}$ & $\mathrm{E}_{1}$ & $\mathrm{E}_{2}$ & Rataan & BNJ (0.05) \\
\hline $\mathrm{J}_{1}$ & $4.20^{\mathrm{a}}$ & $4.52^{\mathrm{a}}$ & $5.92^{\mathrm{b}}$ & $4.88^{\mathrm{a}}$ & \\
$\mathrm{J}_{2}$ & $5.13^{\mathrm{ab}}$ & $6.39^{\mathrm{cd}}$ & $8.36^{\mathrm{e}}$ & $6.63^{\mathrm{b}}$ & \multirow{2}{*}{1,21} \\
$\mathrm{~J}_{3}$ & $5.76^{\mathrm{bc}}$ & $7.58^{\mathrm{de}}$ & $11.07^{\mathrm{f}}$ & $8.14^{\mathrm{c}}$ & \\
\cline { 1 - 4 } Rataan & $5.03^{\mathrm{a}}$ & $6.16^{\mathrm{a}}$ & $8.45^{\mathrm{b}}$ & & \\
\hline
\end{tabular}

Keterangan: Angka-angka yang diikuti oleh huruf yang berbeda berarti berbeda nyata pada taraf uji BNJ 0,05

Hasil uji BNJ pada Tabel 19 menunjukan bahwa perlakuan jarak tanam $60 \mathrm{~cm} \times 60 \mathrm{~cm}\left(\mathrm{~J}_{3}\right)$ memberikan nilai rata-rata tertinggi untuk berat buah per hektar tanaman cabai rawit panen III yaitu 8,14 ton, berbedanyata dengan perlakuan jarak tanam $50 \mathrm{~cm} \times 50 \mathrm{~cm}\left(\mathrm{~J}_{2}\right)$ dan perlakuan $\mathrm{J}_{1}(40$ $\mathrm{cm} \times 60 \mathrm{~cm}$ ). Perlakuan $\mathrm{J}_{2}$ dan $\mathrm{J}_{1}$ berbeda nyata.

Pemberian EM-4 dengan konsentrasi 300 1/ha $\left(E_{2}\right)$ memberikan nilai rata-rata tertinggi untuk berat buah per hektar tanaman cabai rawit panen III yaitu 8,45 ton, berbedanyata dengan perlakuan $E_{1}(150 \mathrm{~L} / \mathrm{ha})$ dan perlakuan $E_{0}$ (tanpa EM-4/kontrol). Perlakuan E1 dan E 0 berbeda tidak nyata.

Interaksi antara jarak tanam $60 \mathrm{~cm} \times 60 \mathrm{~cm}$ dan $\quad \mathrm{EM}_{-4}$ konsentarasi $300 \quad$ 1/ha $\quad\left(\mathrm{J}_{3} \mathrm{E}_{2}\right)$ memberikan berat buah per hektar tertinggi tanaman cabai rawit panen III yaitu 11.07 ton berbeda nyata dengan semua kombinasi perlakuan lainnya.

\subsection{Pembahasan}

Pertumbuhan tanaman adalah perkembangan maju suatu tanaman. Perkembangan ini dapat dinyatakan dengan berbagai cara, mulai dari bagian tertentu suatu tanaman, sampai jumlah total perkembangan tanaman, dan dilafalkan dalam batasan berat kering, panjang, tinggi atau garis tengah tubuh tanaman atau tubuh total tanaman (Poerwowidodo, 1992). Pertumbuhan dan perkembangan disamping ditentukan oleh sifat 
fisik genetik tanaman, juga dipengaruhi oleh faktor lingkungan yang meliputi iklim, unsur hara dan air merupakan hal yang sangat berpengaruh terhadap proses dan aktifitas dalam tubuh tanaman (Sri Setyati, 1991).

Pertumbuhan vegetatif yang diikuti oleh pertumbuhan generatif yang baik memungkinkan produksi optimal akan tercapai. Sebaliknya produksi akan rendah apabila pertumbuhan vegetatif dan generatif mengalami tekanan. Hasil akhir dari tanaman berupa tingkat produksi yang dicapai dapat dikatakan sangat tergantung oleh laju pertumbuhan vegetatif dan pertumbuhan generatif.

Hasil percobaan dapat dilihat bahwa penggunaan jarak tanam yang berbeda memberikan pengaruh yang nyata terhadap parameter yang diamati. Ini dapat terlihat pada tinggi tanaman, jumlah cabang, jumlah bunga, jumlah buah, berat buah per tanaman, berat buah per petak dan berat buah per hektar,begitu pupa pemberian EM-4yang berbeda memberikan pengaruh yang nyata pada semua vriabel yang diamati.

Jarak tanam dan EM-4 serta interaksinya memberikan pengaruh yang nyata terhadap variabel tinggi tanaman, tanaman cabai rawit umur 14, 28, 42 dan 56 HST (Tabel 2, 3, 4 dan 5). Hasil penelitian membuktikan bahwa pengaturan jarak tanam dan pemberian pupuk EM-4 memberikan respon yang baik terhadap tinggi tanaman (Tabel 2, 3, 4 dan 5).

Hasil analisis ragam menunjukan bahwa tinggi tanaman umur 14, 28, 42 dan 56 HST, jumlah cabang, jumlah bunga, jumlah buah, berat buah per tanaman, berat buah per petak dan berat buah per hektar yang diperoleh pada perlakuan $\mathrm{J}_{3}$ (jarak tanam $60 \mathrm{~cm} \times 60 \mathrm{~cm}$ ) lebih baik dari perlakuan jarak tanam lainnya. Hal ini disebabkan karena pada perlakuan $\mathrm{J}_{3}$ pengaruh persaingan dalam penyerapan hara, air dan cahaya matahari lebih baik jika dibandingkan dengan $\mathrm{J}_{2}$ dan $\mathrm{J}_{1}$, sehingga hasil tinggi tanaman yang didapat lebih baik. Hal ini sejalan dengan pendapat Srisetyati (1979) mengatakan bahwa jarak tanam mempengaruhi populasi tanaman per satuan luas tertentu, keefisienan penggunaan cahaya mempengaruhi kompetisi antara tanaman dalam menggunakan air dan zat hara dengan demikian akan mempengaruhi hasil. Selanjutnya dikemukakan bahwa pada umumnya produksi tiap satuan luas yang tinggi, disebabkan tercapainya penggunaan cahaya secara maksimal diawal tumbuh. Akan tetapi pada akhirnya penampilan masing-masing tanaman secara individu menurun karena persaingan untuk memperoleh cahaya dan faktor-faktor tumbuh lainnya. Selanjutnya menurut Palangkung dan Budiarti (1991) mengatakan bahwa produksi maksimal dapat dicapai apabila menggunakan jarak tanam yang tepat sebab semakin tinggi tingkat kerapatan suatu pertanaman akan mengakibatkan semakin besar tingkat persaingan antara tanaman dalam hal mendapatkan unsur hara dan sinar matahari. Untuk mendapatkan jarak tanam yang tepat ada beberapa hal yang perlu diperhatikan antara lain, kesuburan tanah dan lebar sempitnya tajuk tanaman. Semakin subur tanah yang digunakan sebaiknya jarak tanam dipersempit, dan semakin lebar tajuk tanaman, sebaiknya jarak tanam diperlebar karena tanaman membutuhkan tempat tumbuh yang seimbang dengan lingkaran tajuk daunnya.Penetapan jarak tanam pada suatu pertanaman secara agronomi sangat menentukan tingkat produktifitas. Jarak tanam yang terlalu rapat berarti jumlah tanaman per satuan luas sangat besar yang berakibatkan menurunnya hasil, dan juga sebaliknya apabila digunakan jarak tanam yang terlalu lebar akan diperoleh produksi yang maksimal (Aliudin, 1998) dalam Aisyah, 2004.

Jarak tanam yang digunakan akan menentukan mikrohabitat bagi kehidupan hama dan musuh alaminya, misalnya apabila jarak tanam terlalu dekat akan membuat mikrohabitat akan menjadi lembab dan sebaliknya apabila jarak tanam yang terlalu besar maka mikrohabitatnya lebih kering. Oleh karena itu secara tidak langsung jarak tanam dapat akan mengakibatkan tanah disekitar pertanaman menjadi lembab karena kurangnya sinaran surya sehingga dapat menguntungkan bagi kehidupan hama.

Menurut Haryadi (1979) dalam Aisyah (2004), pengaturan jarak tanam mempermudah dalam kegiatan seperti penyiangan, pemupukan dan proteksi tanaman. Penanaman suatu tanaman sebaiknya dilakukan dengan jarak tanam yang 
sesuai dan teratur karena dapat memudahkan pemeliharaan, pemanenan dan dapat mengurangi gulma. Jarak tanam merupakan salah satu faktor penting untuk mendapatkan hasil yang tinggi dan maksimal.

Pada dasarnya pemakaian jarak tanam yang rapat bertujuan untuk meningkatkan hasil, asalkan faktor pembatas dapat dihindari sehingga tidak terjadi persaingan antar tanaman. Disamping itu pengaturan jarak tanam yang tepat juga dapat menekan pertumbuhan gulma, karena pertumbuhan tajuk dapat dengan cepat menutupi permukaan tanah, bila jarak tanam atau antar baris tanaman terlalu lebar maka akan memberikan kesempatan kepada gulma untuk dapat tumbuh dengan baik (Waxn and Stoller, 1977) dalam Ari Mayadewi, 2007.

Selanjutnya menurut Resiworo, 1992 dalam Nyoman, 2007 menyatakan bahwa jarak tanam yang rapat akan meningkatkan daya saing tanaman terhadap gulma karena tajuk tanaman menghambat pancaran cahaya ke permukaan sehingga pertumbuhan gulma menjadi terhambat disamping laju evaporasi dapat ditekan. Namun pada jarak tanam yang terlalu sempit menyebabkan tanaman budidaya akan memberikan hasil yang relatif kurang karena adanya kompetisi antar tanaman itu sendiri.

Hasil analisis ragam menunjukan bahwa tinggi tanaman umur 14, 28, 42 dan 56 HST jumlah cabang, jumlah bunga, jumlah buah, berat buah per tanaman, berat buah per petak dan berat buah per hektar yang diperoleh pada perlakuan EM-4 dengan konsentrasi $300 \mathrm{~L} / \mathrm{ha}\left(\mathrm{E}_{2}\right)$ lebih baik dari perlakuan pemberian EM-4 lainnya. Hal tersebut disebabkan karena kemampuan konsentrasi efektifitas mikroorganisme (EM-4) dalam meningkatkan jumlah pengikatan Nitrogen bebas oleh bakteri yang dikandungnya sehingga keadaan unsur hara dalam tanah dalam keadaan cukup seimbang bagi tanaman cabai merah untuk proses pertumbuhannya. Hal ini sejalan dengan pendapat Sri setyati (2001), menyatakan bahwa pertumbuhan dan produksi disamping ditentukan oleh sifat fisik genetik tanaman juga dipengaruhi oleh faktor lingkungan yang meliputi iklim, unsur hara dan air merupakan hal yang sangat berpengaruh terhadap proses dan aktifitas dalam tubuh tanaman. Pertumbuhan tanaman ditentukan oleh pertumbuhan ukuran dan berat segar tanaman yang tidak mudah dibalik, yang mencerminkan bertambahnya protoplasma. Oleh sebab itu usaha untuk memperoleh pertumbuhan tanaman yang baik, faktor tumbuh harus berada dalam keadaan optimal dan tersedia dalam jumlah yang cukup dan seimbang.Hal di atas sejalan dengan pendapat Sri setyati (2001), menyatakan bahwa : pertumbuhan dan produksi disamping ditentukan oleh sifat fisik genetik tanaman juga dipengaruhi oleh faktor lingkungan yang meliputi iklim, unsur hara dan air merupakan hal yang sangat berpengaruh terhadap proses dan aktifitas dalam tubuh tanaman. Pertumbuhan tanaman ditentukan oleh pertumbuhan ukuran dan berat segar tanaman yang tidak mudah dibalik, yang mencerminkan bertambahnya protoplasma. Oleh sebab itu usaha untuk memperoleh pertumbuhan tanaman yang baik, faktor tumbuh harus berada dalam keadaan optimal dan tersedia dalam jumlah yang cukup dan seimbang. Pertumbuhan dari organ penyimpan (storage) dipengaruhi oleh faktor lingkungan dan genetik, faktor - faktor ini secara langsung juga mempengaruhi laju fotosintesa. Keserasian hubungan antara fase vegetatif dan fase generatif dari perkembangan tanaman karena adanya perubahan lingkungan tumbuh, lama penyinaran, suhu, air dan sebagainya selama musim tumbuh adalah penting untuk memperoleh hasil - hasil maksimum (Basri Jumin, 2002). Pemberian EM-4 yang berlebihan berpengaruh juga terhadap produksi tanaman, dimana diketahui EM-4 itu sendiri dapat menampung air. Jadi semakin banyak EM-4 yang diberikan semakin banyak air yang ditampung. Disamping curah hujan yang tinggi otomatis proses fotosintesis berkurang, ini berpengaruh terhadap hasil produksi. Kecenderungan penurunan pertumbuhan akibat peningkatan konsentrasi, sesuai dengan yang dikemukakan oleh Agustina (1998) yang dikenal dengan hukum kenaikan hasil yang semakin berkurang, bahwa hubungan antara penambahan nutrisi dengan status nutrisi yang rendah apabila dicukupi maka pengaruhnya terhadap hasil tanaman, ini artinya bahwa penambahan nutrisi pada tingkat tertentu 
masih dapat menaikan hasil dan penambahan selanjutnya cenderung menurunkan hasil tanaman.Pemberian EM4 pada dasarnya memperbaiki struktur tanah, menambah bahan organik tanah, dan meningkatkan $\mathrm{pH}$ tanah. Untuk mendapatkan efisiensi pemupukan, pupuk harus diberikan dalam jumlah yang mencukupi kebutuhan tanaman. Pemberian EM4pada dasarnya yang diberikan adalah bahan organik, dimana bahan organik tersebut mempertinggi kesuburan tanah dengan merubah struktur tanah menjadi gembur dan juga menjadi sumber hara bagi tanaman, maka dari itu tanah yang subur dan gembur banyak menyimpan air sehingga unsur hara yang tersedia di dalam tanah mudah larut dan akar tanaman lebih leluasa dalam menyerap unsur hara.

MenurutBintoro et. al (1990) dalam Basri Jumin (2002) melaporkan bahwa penambahan bahan organik pada tanah mengurangi stres tanaman dan dapat meningkatkan hasil produksi. Selanjutnya menurut Pranata (2002) menyatakan bahwa fungsi EM-4 untuk mengaktifkan bakteri pelarut, meningkatkan kandungan humus tanah lachtobacillus, sehingga mampu memfermentasikan bahan organik menjadi asam animo. Disamping itu dengan adanya aktifitas mikroorganisme yang bermanfaat bagi tanah maupun tanaman yang terdapat pada larutan EM4 sehingga mampu mengurai bahan organic menjadi senyawa-senyawa yang sangat penting dalam pertumbuhan dan produksi tanaman seledri. Menurut Sutanto (2002), EM-4 merupakan Suatu kultur campuran berbagai mikroorganisme yang bermanfaat (terutama bakteri fotosintesis, bakteri asam laktat, ragi actinomycetos) dan jamur peragian yang dapat digunakan sebagai makanan untuk meningkatkan keragaman mikroba tanah, sehingga diharapkan dapat memperbaiki kesehatan dan kualitas tanah yang selanjutnya akan mampu meningkatkan produksi dan pertumbuhan tanaman. EM-4 tidak mengandung zat membahayakan maupun mikroorganisme hasil rekayasa genetic karena EM-4 mengandung kultur campuran berbagai mikroba yang terdapat dalam lingkungan alam yang bersifat menguntungkan.

Aplikasi EM-4 mempunyai beberapa keuntungan, salah satunya adalah menekan pertumbuhan hama penyakit tanaman dalam tanah, membantu meningkatkan kapasitas fotosintetis tanaman, membantu proses penyerapan dan penyaluran unsur hara dari akar ke daun, dan meningkatkan kualitas bahan organik sebagai pupuk, disamping itu juga dapat meningkatkan kualitas pertumbuhan vegetatif dan generatif tanaman seperti perkecambahan, pembungan, pembentukan buah dan proses pematangan buah. Aplikasi EM-4 juga ramah lingkungan dan tidak meninggalkan resiko.

Kombinasi perlakuan pengaturan jarak tanam dan pemberian EM-4 berpengaruh nyata terhadap semua variabel yang diamati. Interaksi antara jarak tanam $60 \mathrm{~cm} \times 60 \mathrm{~cm}$ dan pemberian EM-4 $300 \mathrm{~L} / \mathrm{ha}\left(\mathrm{J}_{3} \mathrm{E}_{2}\right)$ memberikan pengaruh yang terbaik jika dibandingkan dengan kombinasi perlakuan lainnya. Interaksi dapat terjadi apabila dari beberapa faktor yang dicobakan saling tergantung satu sama lain. Pertumbuhan tanaman yang baik ditandai dengan penampilan batang, cabang dan daun tumbuh subur sehingga fotosintesis akan berlangsung dengan baik. Dengan demikian fotosintesis yang dihasilkan lebih banyak dan pada gilirannya fotosintat tersebut akan digunakan untuk pertumbuhan tinggi tanaman dan pada fase generatif. Ketersediaan unsur hara yang disuplay oleh penggunaan EM-4 dan pengaturan jarak tanam yang tepat menyebabkan terjadinya aktifitas penerimaan cahaya matahari yang baik yang pada akhirnya digunakan oleh tanaman dalam proses fotosintesis secara optimal sehingga dapat memacuh pertumbuhan tanaman dengan baik. Pendugaan ini sejalan dengan pendapat Sarief (1985) bahwa dengan ketersediaan unsur hara dan air di dalam tanah guna diserap oleh tanaman akan mempengaruhi laju fotosintesis semakin banyak tanaman menyerap air dan unsur hara maka laju fotosintesis akan semakin meningkat. Dengan demikian meningkatnya laju fotosintesis akan menyebabkan jumlah fotosintat yang dihasilkan lebih banyak pada bagian generatif tanaman.

\section{PENUTUP}

Hasil dan pembahasan di dapat bahwa penggunaan jarak tanam $60 \mathrm{~cm} \times 60 \mathrm{~cm}\left(\mathrm{~J}_{3}\right)$ memberikan pengaruh yang baik terhadap tinggi 
tanaman, jumlah cabang, jumlah bunga, jumlah buah, berat buah per tanaman, berat buah per petak dan berat buah per hektar., Perlakuan EM-4 konsentrasi $300 \mathrm{~L} / \mathrm{ha}\left(\mathrm{E}_{2}\right)$ memberikan pengaruh yang baik terhadap tinggi tanaman, jumlah cabang, jumlah bunga, jumlah buah, berat buah per tanaman, berat buah per petak dan berat buah per hektar dan interaksi antara jarak tanam $60 \mathrm{~cm} \times 60 \mathrm{~cm}$ dan EM-4 konsentrasi $300 \mathrm{~L} / \mathrm{ha}$ $\left(\mathrm{J}_{3} \mathrm{E}_{2}\right)$ menghasilkan produksi berat buah per hektar yang terbaik yaitu 11,07 ton.
Untuk meningkatkan produksi cabai rawit disarankan agar sebaiknya menggunakan jarak tanam $60 \mathrm{~cm} \times 60 \mathrm{~cm}$ dan konsentrasi pupuk EM-4 $300 \mathrm{~L} / \mathrm{ha}$ karena penelitian ini telah membuktikan hasil yang maksimal dari kombinasi perlakuan di atas, serta perlu dilakukan penelitian lanjutan pada kondisi lapang dengan memperhatikan lingkungan tumbuh tanaman cabai rawit.

\section{DAFTAR PUSTAKA}

Hanafia,K.A.2009 Perancangan percobaan. PT. Raja Grafindo persada.

Hidayat. 2008. Pengaruh jarak tanam. Tubus.No.247. Jakarta.

Novizan 2002. Petunjuk pemupukan yang efektif. Agro Media pustaka, Depok.

Petunjuk penggunaan EM4. ( http:// EM4-Indonesia.com/cabai-rimbun-dan produksi/11/11/2016.

Rahman S. 2010. Meraup untuk bertanam cabai rawit dengan polybag. Penerbit Lily publiser Yogyakarta.

Setiadi. 2008. Bertanam cabai rawit. Penerba swadaya, Jakarta.

Setyamidjaja, 2000. D. Pupuk dan pemupukan, (Jakarta:simplek).

Siswadi, 2006. Bertanam sayuran secara vertikultura. Penerbit Citra Ajjiparama Yogyakarta. Sutedjo MM, 2008. Pupuk dan cara pemupukan. Rineka Cipta. Jakarta.

Wahyuhidayat, 1999. Pengaruh jarak tanam dan faktor-faktor pertumbuhan, Penerbit PT swadaya, Depok. 